\title{
How freezing methods affect the sensory profile of pasteurized and unpasteurized mangaba pulp
}

\section{Como os métodos de congelamento afetam o perfil sensorial da polpa de mangaba pasteurizada e não pasteurizada}

\author{
Gilma Auxiliadora Santos Gonçalves ${ }^{1 *}(\mathbb{D})$, Nathane Silva Resende ${ }^{2}$ (D) Carla Saraiva Gonçalves ${ }^{3}(\mathbb{D})$, \\ Elisângela Elena Nunes de Carvalho ${ }^{3}$ D , Jaime Vilela de Resende $^{3}\left(\mathbb{D}\right.$, Eduardo Valério de Barros Vilas Boas ${ }^{3}$
}

1'Instituto Federal de Educação, Ciência e Tecnologia do Sudeste/IF Sudeste, Campus Barbacena, Barbacena, MG, Brasil

${ }^{2}$ Faculdade Única de Ipatinga, Ipatinga, MG, Brasil

3Universidade Federal de Lavras/UFLA, Departamento de Ciência de Alimentos/DCA, Lavras, MG, Brasil

*Corresponding author: gilma.goncalves@ifsudestemg.edu.br

Received in February 7, 2020 and approved in June 23, 2020

\begin{abstract}
The Mangaba, an exotic fruit of the Brazilian Cerrado, is very appreciated for its peculiar sensory characteristics. Here we aimed to evaluate the sensory profile of mangaba pulp subjected to three treatments (unpasteurized and pasteurized pulps; frozen by static air and forced air; stored frozen for zero, 4, 8 and 12 months). The following sensory tests were applied: temporal dominance of sensations (TDS) (identify and check the dominant sensations of flavor over time of consumption), ideal scale (identify optimal concentration of sucrose to be added in nectar) and acceptance test (to evaluate the effect of treatments on consumer acceptance). By TDS analyses, a sour taste was reported for most treatments, combined with the identification of a bad flavor in most pulps from 8 months of frozen storage. The ideal scale determined that $87.8 \mathrm{~g} / \mathrm{L}$ sucrose should be added to the mangaba nectar. The frozen methods by static air or forced air did not significantly influence the sensory acceptance of the mangaba pulp. Pasteurization favors high mangaba pulp acceptance for up to 8 months, however, by 12 months of storage, treatments still have good sensory acceptance.
\end{abstract}

Index terms: Hancornia speciosa Gomes; temporal dominance of sensations; Just-About-Right-Scale; acceptance test; sensory quality.

\begin{abstract}
RESUMO
A Mangaba, fruto exótico do cerrado brasileiro, é muito apreciada por suas características sensoriais peculiares. Aqui, objetivamos avaliar o perfil sensorial da polpa de mangaba submetida a três tratamentos (polpas não pasteurizadas e pasteurizadas; congeladas por ar estático e ar forçado; armazenadas congeladas por zero, 4, 8 e 12 meses). Foram aplicados os seguintes testes sensoriais: dominância temporal das sensações (TDS) (identificar sensações dominantes do sabor ao longo do tempo de consumo), escala ideal (identificar a concentração ideal de sacarose a ser adicionada ao néctar) e teste de aceitação (avaliar o efeito dos tratamentos na aceitação do consumidor). O TDS, identificou o gosto ácido na maioria dos tratamentos, combinado com a identificação de um sabor ruim na maioria das polpas a partir de 8 meses de armazenamento congelado. A escala ideal determinou que 87,8 g l L de sacarose seja adicionada ao néctar de mangaba. Os métodos de congelamentos não influenciaram a aceitação das polpas. A pasteurização favorece maior aceitação da polpa de mangaba por até 8 meses, no entanto, aos 12 meses de armazenamento, os tratamentos ainda apresentam boa aceitação sensorial.
\end{abstract}

Termos para indexação: Hancornia speciosa Gomes; dominância temporal de sensações; escala do ideal; teste de aceitação; qualidade sensorial.

\section{INTRODUCTION}

Among the fruits with high nutritional and bioactive value, mangaba (Hancornia speciosa Gomes), an exotic fruit of the Brazilian Cerrado of the Apocynaceae family, contains high levels of vitamin C, vitamin E, folic acid, carotenoids, and phenolic compounds, in addition to high antioxidant capacity, and has aroused great interest for its beneficial health effects demonstrated in recent research (Reis et al., 2019; Lima et al., 2015; Pereira et al., 2015).

Mangaba is also appreciated because of its flavor characteristics and peculiar aroma, having yellow fleshy viscous pulp with a soft, sweet flavor and a sour taste (Venturini Filho, 2010), presenting great potential for exploration in the tropical fruit segment. 
Although in recent years there has been an increase in demand for low-processed foods, similar to fresh fruits and vegetables and without additives, the great challenge for the food industry is to extend the shelf life of these foods, using technologies that minimally affect their nutritional and sensory properties (Picouet et al., 2016).

Pasteurization, although it can increase storage time, it can cause significant sensory changes, such as color, aroma and flavor degradation (Garcia-Reyes; Narvaez-Cuenca, 2010; Su et al., 2019; Bhattacharjee; Saxena; Dutta, 2019), especially when associated with freezing and prolonged storage. In the absence of studies evaluating the effect of prolonged storage on the sensory profile of processed fruits.

Multiple sensory tests should be applied to foods to satisfactorily evaluate changes that occur in processed and stored fruits. The Temporal Dominance of Sensations test (TDS), a temporal descriptive test, is used to identify the sensation that is dominant over time from among a sequence of sensory attributes (Pineau et al., 2009) The term "Dominant" is considered as the sensation that attracts attention, the most striking perception, or the new sensation that appears at a certain moment, not necessarily the most intense (Labbe et al., 2009; Pineau et al., 2009). Some studies have used TDS to profile the dynamic perception of drinking (Frost; Harbertson; Heymann, 2017; Hutchings et al., 2017) and others was successfully applied to beverages like strawberry pulp (Gonçalves et al., 2017) and lemonade (Wu et al., 2019).

The ideal scale, most commonly called a Just-aboutright (JAR) scale, seeks to identify the optimal amount of a particular component to be added for improving the acceptance of a product (Vickers, 1988). Studies using the JAR scale that have been carried out to identify the ideal sweetness of fruit nectars (Pineli et al., 2016; Gonçalves et al., 2017; Lima et al., 2018). Considering that mangaba nectar is still commercialized on a large scale, it is justified to identify the ideal sucrose content to be added to the drink, for better consumer acceptance.

In order to complement the results of the TDS and Just-about-right scale, the acceptance test can be applied, as it allows to reveal specific characteristics that determine greater or lesser acceptance of a food. In this sense, studies have been successfully applying sensory acceptance for the evaluation of fruit drinks from the Brazilian Cerrado (Perfeito; Corrêa; Peixoto, 2017; Rocha et al., 2008, Figueiredo et al., 2019; Gomes et al., 2020).

Few studies have been devoted to the sensory evaluation of mangaba derivatives (Assumpção et al., 2013; Silva et al., 2015), they merely identify the acceptance of the product, not considering the storage period. After an extensive literature review, no articles were found on the effect of the simultaneous application of conservation techniques to the pulp of this fruit during long-term storage. Thus, this study aims to determine the sensory and physicochemical profiles of frozen mangaba pulp following long-term storage.

\section{MATERIAL AND METHODS}

\section{Collection and preparation of samples}

As raw materials we used Mangaba (Hancornia speciosa Gomes) from the municipality of Curvelo, Minas Gerais, Brazil (latitude $18^{\circ} 45^{\prime} 23^{\prime \prime} \mathrm{S}$, longitude $44^{\circ}$ $25^{\prime} 51^{\prime \prime} \mathrm{W}$ and altitude $632 \mathrm{~m}$ ). The fruits were pre-washed, sanitized in sodium hypochlorite solution $\left(100 \mathrm{mg} \mathrm{L}^{-1}\right.$ for $15 \mathrm{~min}$ ), and de-pulped in a pulper (Bonina, model 0.25 DF). Pulps were packed (Hubber, model DMM20 manual liquid filler-doser) in low-density polyethylene bags (100 g per pack), sealed in a Termosolder pedal sealer (R. Baião, model 3138).

Half of the package obtained was subjected to pasteurization $\left(85^{\circ} \mathrm{C}\right.$ for $5 \mathrm{~min}$ ) and chilled immediately in an ice bath. The unpasteurized pulps were frozen immediately. Both types of pulp, pasteurized (P) and unpasteurized (UP), were divided into two lots and frozen by forced air (FA) (freezing chamber with forced air). The air velocity was measured at different locations in the chamber using a hot wire anemometer TSI 9535USA. The average air velocity was $1.78 \pm 0.08 \mathrm{~m} \mathrm{~s}^{-1}$, and the air cooling temperature was $-25 \pm 3{ }^{\circ} \mathrm{C}$ for $10 \mathrm{~h}$ or $\left(-18{ }^{\circ} \mathrm{C}\right.$ by static air [SA]). Pulps were stored in a horizontal freezer (Cônsul, model CHA31C) at $-18^{\circ} \mathrm{C}$ for 12 months.

The pulps were analyzed at time zero. The physical and chemical analyses were carried out every 3 months, and sensory and microbiological analyses were carried out every four months, for 12 months. The samples were thawed under running water.

\section{Microbiological analysis}

Quantification of filamentous fungi and yeast were conducted. Quantification of coliforms at $35{ }^{\circ} \mathrm{C}$ and $45{ }^{\circ} \mathrm{C}$, presence or absence of Salmonella sp. and aerobic psychrotrophic count were conducted according to methodologies described by the International Commission on Microbiological Specifications for Foods (Silva et al., 2007). Analyses were performed immediately prior to application of sensory tests. 


\section{Sensory analysis}

This experiment was approved by the Ethics Committee of the Federal University of Lavras (approval number 502.167). Sensory analyses were performed in the Sensory Analysis Laboratory of the Food Science Department at the Federal University of Lavras. All the tests were carried, without repetition and without training, out with students, professors, employees and other frequenters of the university, over 18 years old, of both sexes and usually consume fruit juices. The samples were presented monadically (Macfie et al., 1989) at an average temperature of $5^{\circ} \mathrm{C}$ in disposable white cups encoded with three-digit numbers, in balanced order.

\section{Temporal Dominance of Sensations (TDS)}

The TDS test was applied to the treatments and times shown in Table 1, except for the following case: at time zero, the TDS test was only applied to the freshly prepared pasteurized (P) and unpasteurized (UP) samples, because the effects of differential freezing methods (SA vs. FA) on taste sensations at this point did not apply. In total, 40 evaluators, untrained were instructed about the temporality of sensations and were thoroughly oriented on the use of the SensoMaker data acquisition program (Pinheiro et al., 2013). The pulps were served pure (that is, not diluted or sweetened). The evaluators were instructed on the meaning of the dominant flavor and asked about any eventual doubts they might still have.

After instructions, evaluators were asked to click 'Start' and, in two seconds, place a mangaba pulp sample (approximately $10 \mathrm{~g}$ ) in their mouth, starting the evaluation. For $20 \mathrm{~s}$, using a mouse, participants selected, with one click the dominant flavor during the pre-set time, the attributes that appeared on the screen (sweet, sour, cooked taste, tasteless, bad taste, fermented, bitter, metallic, and astringent), which were selected in a pretest to characterize the samples.

TDS curves were calculated according to the method proposed by Pineau et al. (2009), using SensoMaker. In short, two lines were drawn on the TDS graphic display, the "chance level", the dominance rate an attribute can receive by chance, and the "significance level", the minimum rate to be considered significant. This is calculated using the confidence interval for a binomial proportion based on the normal approximation, according to Pineau et al. (2009) using Equation 1:

$$
P S=P o+1.645 \sqrt{\frac{P o(1-P o)}{n}}
$$

Ps: lowest significant proportion value $(\mathrm{a}=0.05)$ at any point in time for a TDS curve; n: number of subjects * replication.

The curves are drawn by subtracting the dominance rates from two samples for each attribute at each point in time. The difference in the dominance rate is only traced when considered significantly different from 0 , according to a classic test of comparison of binomial proportions (Pineau et al., 2009) e os gráficos gerados no excel 2010.

\section{Ideal Scale (Just-about-right-scale)}

The ideal scale was performed to identify the optimal sucrose concentrations needed to sweeten mangaba nectar, a type of non-carbonated soft drink made by crushing fruit pulp. In the preparation of the nectar, the pulp was diluted to generate solutions of $34 \%$ pulp and $66 \%$ water, based on label information from commercially available fruit pulp. The pulp was homogenized using a blender and prepared immediately before testing, then kept refrigerated throughout the analysis. Pre-tests determined the concentrations $(50,75,100,125$ and $150 \mathrm{~g})$ of sucrose per liter of nectar used in the assay, thus, in this test, 5 samples were evaluated

The $30 \mathrm{~mL}$ samples of each formulation were fed to 60 evaluators, who recorded their responses on a specific scale based on how ideal those samples were in relation to sweet taste (Vickers, 1988).

This method asks the evaluators evaluate samples according to an ideal range, anchored at the extremes by "extremely less sweet than ideal (-4)" and "extremely sweeter than ideal $(+4)$ ", with the ideal flavor being a sweet taste corresponding to 0 (zero).

Linear regression (confidence interval of 95\%) was performed on the JAR scores versus sucrose concentration analysis using the SISVAR program version 5.9 (Ferreira, 2019).

\section{Acceptance Testing}

The acceptance test was applied to evaluate consumer acceptance of mangaba pulp subjected to the treatments described in Table 1. Samples were served as nectar, and the sucrose content was the optimal ratio identified in the ideal Scale. One-hundred consumers participated in the test. Each evaluator received, monadically, $30 \mathrm{~mL}$ of mangaba nectar. Samples were evaluated regarding the attributes appearance, odor, flavor, viscosity, and overall impression, with the verbal hedonic scale of 9 points, ranging from 'dislike extremely' (1) up to 'like extremely' (9) (Stone; Sidel, 1993). 
Table 1: Time and treatments submitted to TDS and acceptance test.

\begin{tabular}{cc}
\hline $\begin{array}{c}\text { Time } \\
\text { (months) }\end{array}$ & Sample/Treatment \\
\hline & Unpasteurized frozen by static air (UPSA) \\
$\begin{array}{cc}\text { Zero, 4, 8 } \\
\text { and 12 }\end{array}$ & $\begin{array}{c}\text { Pnpasteurized frozen by forced air (UPFA) } \\
\end{array}$ \\
& Pasteurized frozen by static air (PSA) \\
\hline
\end{tabular}

The acceptance test was first submitted to ANOVA to assess the interaction between the three factors (nonpasteurized and pasteurized samples; frozen by either forced air or static air methods and storage for up to 12 months (zero $=\mathrm{T} 0,4=\mathrm{T} 4,8=\mathrm{T} 8$, and $12=\mathrm{T} 12$ ), when significant were submitted to polynomial regression analysis and Tukey test at 5\% significance using the program Sisvar 5.9 (Ferreira, 2019).

After a chemometric approach, principal component analysis (PCA) and hierarchical cluster analysis (HCA) were applied using the statistical software $\mathrm{R}$ version 3.3.1 (06-26-2916) (R Development Core Team, 2016) to analyze the samples. Before Chemometrics, all variables were selfstaggered as to the statistical significance of all responses. PCA was applied to separate the pulps $(n=16)$ according to the values of the variables, based on linear correlations. HCA was performed to evaluate similarities among the pulps according to the analyzed variables. In this sense, the similarities of the samples were calculated based on the Euclidean metric, and the Ward method was used to form and to suggest groups of similar samples. A bar graph was also made for the overall impression, containing the count (\%) of the tester's notes.

\section{RESULTS AND DISCUSSION}

\section{Microbiological analysis}

In the current Brazilian legislation, Normative Instruction No.1 from 7 January 2000 (Brasil, 2000) sets maximum microbiological limits for fruit pulp: yeast and molds, maximum $5 \times 10^{3} \mathrm{CFU} \mathrm{g}^{-1}$ for in natura pulp, frozen or not, and $2 \times 10^{3} \mathrm{CFU} \mathrm{g}^{-1}$ for chemically conserved pulp and/or pulp submitted to heat treatment; thermotolerant coliforms, maximum $1 \mathrm{~g}^{-1}$; Salmonella spp - absent in $25 \mathrm{~g}$. To determine additional microbiological characterization, quantification of aerobic psychrotrophic was also conducted. There was no contamination in the samples at any of the times evaluated, showing that the pulps under study are in accordance with current legislation, presenting good microbiological stability during storage.

\section{Sensory analysis}

\section{Temporal Dominance of Sensations (TDS)}

In this study, the evaluators were not trained, considering that, according to some authors, hard training can lead to the indication of descriptors in the same order for all samples, in addition to the possibility of confusing dominance and intensity (Meillon; Urbano; Schlich, 2009; Albert et al., 2012). A study by Rodrigues et al. (2016) observed that consumers can discriminate samples and that training does not seem to improve this level of discrimination.

In TDS tests, the evaluators proved the samples and indicate which sensation is dominant over time until the sensation ends, or another appears as dominant (Pineau et al., 2009). The chart presents two lines: "the chance level" $(0.12)$ and "significance level" $(0.25)$. The "chance level" is the dominance rate that an attribute can obtain by chance and the "significance level" is the minimum value of this ratio considered significant (Pineau et al., 2009). It is noteworthy that TDS dominance curves do not relate the intensity, but the proportion of times an attribute is selected as dominant at any given time. The higher the attribute dominance rate, the better the correlation among the tasters.

The pure mangaba pulps were served without water or sugar, allowing the attributes to be perceived without interference. The TDS profiles for the UP and P mangaba pulps at time zero are shown in Figure 1.

The sour taste was the only one to be perceived in both types of pulps at time zero (Figure 1b). The UP pulp TDS graph shows that the sour taste was perceived after $4 \mathrm{~s}$ and its dominance rate increased to 0.39 (39\% of the tasters perceived this flavor as dominant). In the P pulp, it was also found at $4 \mathrm{~s}$ with a maximum dominance rate of 0.30 . This difference may be related to a loss, alteration or formation of new compounds, since pasteurization can induce loss of aroma and flavor compounds typical of fresh fruit (Costa et al., 2003).

The lack of studies using the TDS technique in fruit pulp limits the opportunity to compare our finding to the literature; however, a recent study with strawberry pulp submitted to treatments similar to that of this study identified sour taste as dominant in pulps P and UP, and the cooked flavor was perceived in pulp $\mathrm{P}$ at the zero storage time (Gonçalves et al., 2017). In another study with blackcurrant juice obtained from pulp, the sour taste was dominant in those produced with a higher pulp concentration $(\mathrm{Ng}$ et 
al., 2012). While other studies did not observe a tendency for participants to identify a dominant taste over others (Nguyen; Naes; Varela., 2018; Wu et al., 2019).

After 4 months of storage, the sour taste was dominant in the UP pulps (SA and FA) (Figure 2A and B) but showed a lower maximum dominance rate $(0.28)$ than at time zero for the two types of pulp. The P pulps showed the cooked flavor as dominant, this being perceived only at the end of the test and at a low dominance rate in the two types of pulp (average of 0.26 ).
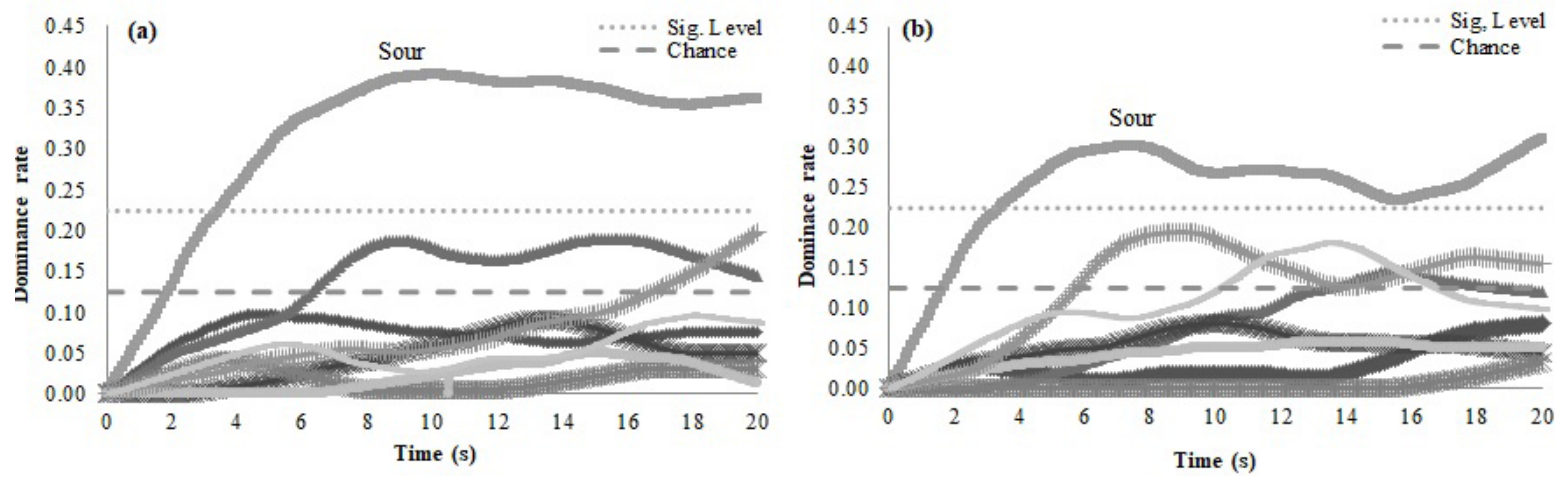

Figure 1: Graphic representation of the temporal dominance of sensations profile generated for Unpasteurized (UP) (a) and Pasteurized (P) (b) freshly prepared mangaba pulp.
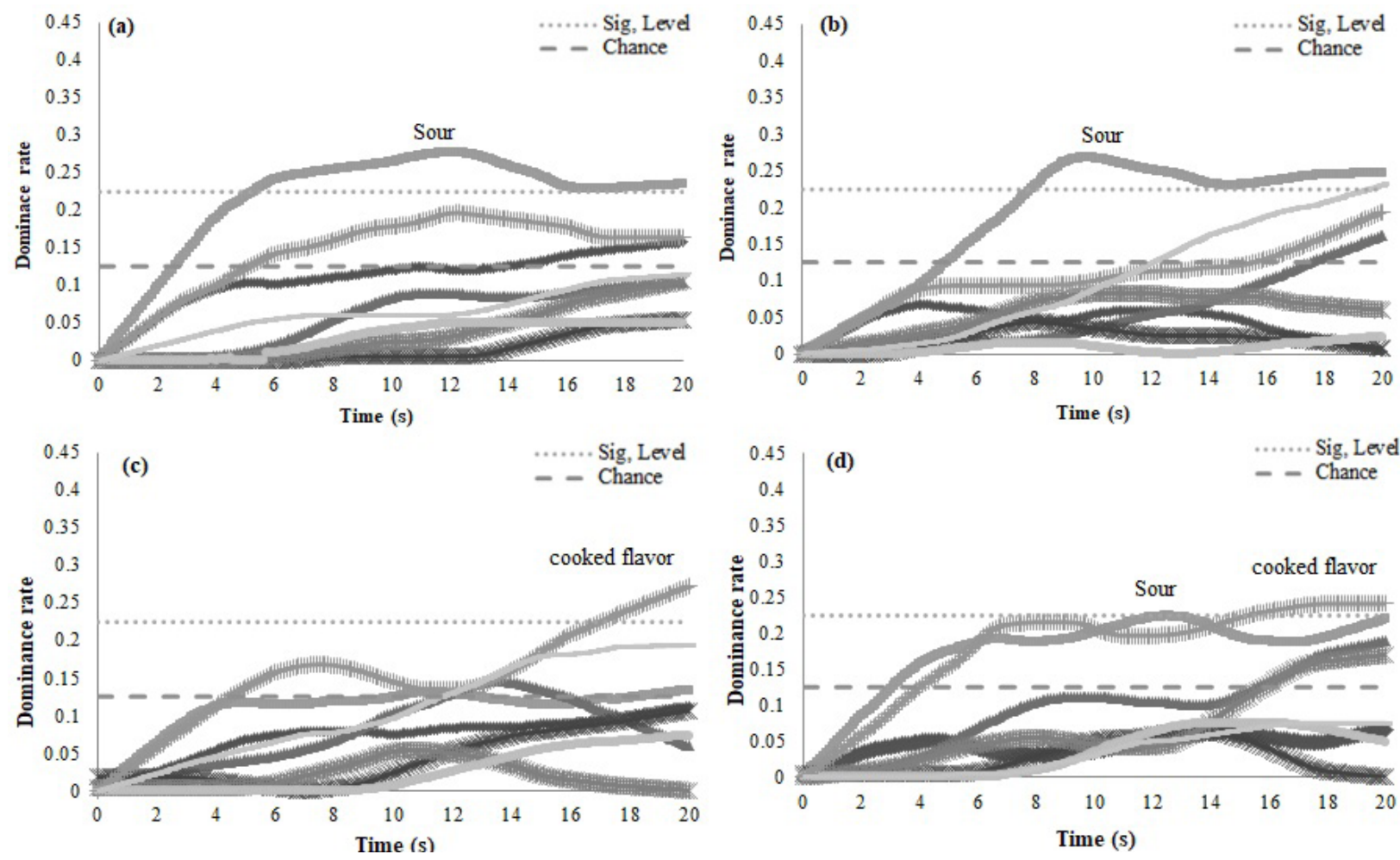

Figure 2: Graphic representation of the temporal dominance of sensations profile generated for mangaba pulp Unpasteurized, frozen by Static Air (UPSA) (a); Unpasteurized by frozen by Forced Air (UPFA) (b); Pasteurized frozen by Static Air (PSA) (c); and Pasteurized frozen by Forced Air (PFA) (d) stored for 4 months. 
The perception of the cooked flavor is justified by the heat treatment applied to the pulps. Although pasteurization may promote the perception of the taste cooked in fruits, it can be inferred that the mangaba pulps, when pasteurized, will not always present that taste, as it was perceived as dominant only after 4 months of storage and at a low dominance rate (only $25 \%$ of the evaluators cited it), regardless of the freezing method (Figure 2A-D). The cooked flavor was previously identified by Hurtado et al. (2015) in multi-fruit smoothies made with fruit in proportions similar to those used in commercial smoothies.

At 8 months of storage, in addition to the sour taste, a bad flavor was identified in the UP pulps (Figure 3A). This was perceived in UPSA (Figure 3B) pulp with a maximum dominance rate of 0.28 , whereas this value was 0.27 for the UPFA pulp. The bad flavor was also perceived in the pulp PSA (Figure $3 C)$. The identification of bad flavor can indicate flavor deterioration with increased time in mangaba pulp. At
8 months of storage only in the PFA pulp the bad flavor was not perceived (Figure 3D).

The TDS test identified the perception of a bad flavor from the mangaba pulp following long-term storage, which contributed to a decline in acceptability. This could not have been achieved using the static sensory test.

At the end of the storage period, the sour taste was again dominant (Figure 4A-D), followed by the bad flavor that was perceived in most samples, reinforcing that the increase in time compromises the sensory quality of the stored mangaba pulp, even if at a low rate of maximum dominance (0.27) in UPFA pulp (Figura 4B). Gonçalves et al. (2017) applied the TDS to evaluate strawberry pulps submitted or not to pasteurization and frozen by different methods during six months of storage and identified sour taste at all times and treatments.

In general, the pasteurization and shorter storage time were more efficient in retaining the original flavor of the mangaba pulp compared to not pasteurized, long-term stored samples.
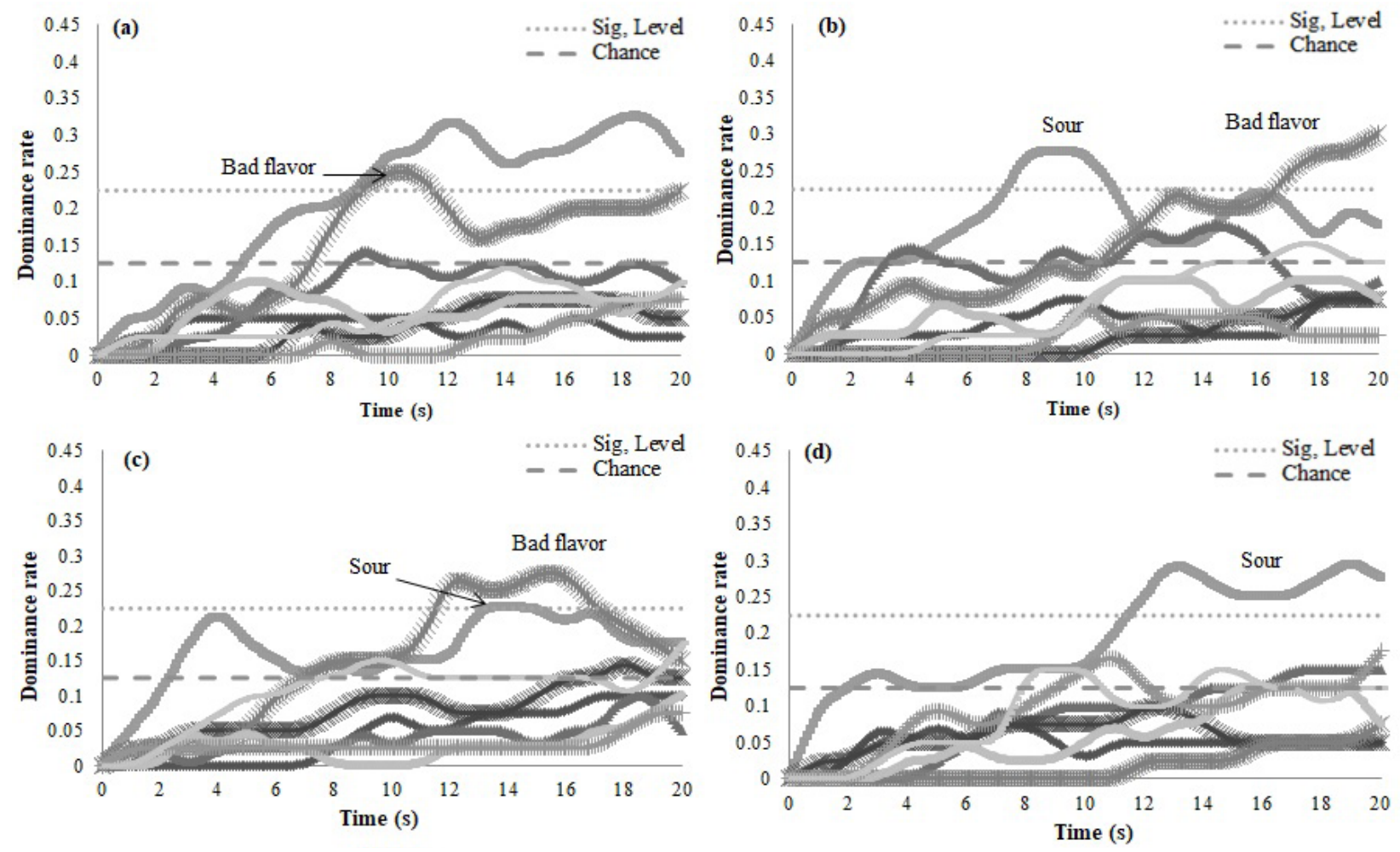

Figure 3: Graphic representation of the temporal dominance of sensations profile generated for mangaba pulp Unpasteurized, frozen by Static Air (UPSA) (a); Unpasteurized by frozen by Forced Air (UPFA) (b); Pasteurized frozen by Static Air (PSA) (c); and Pasteurized frozen by Forced Air (PFA) (d) stored for 8 months. 

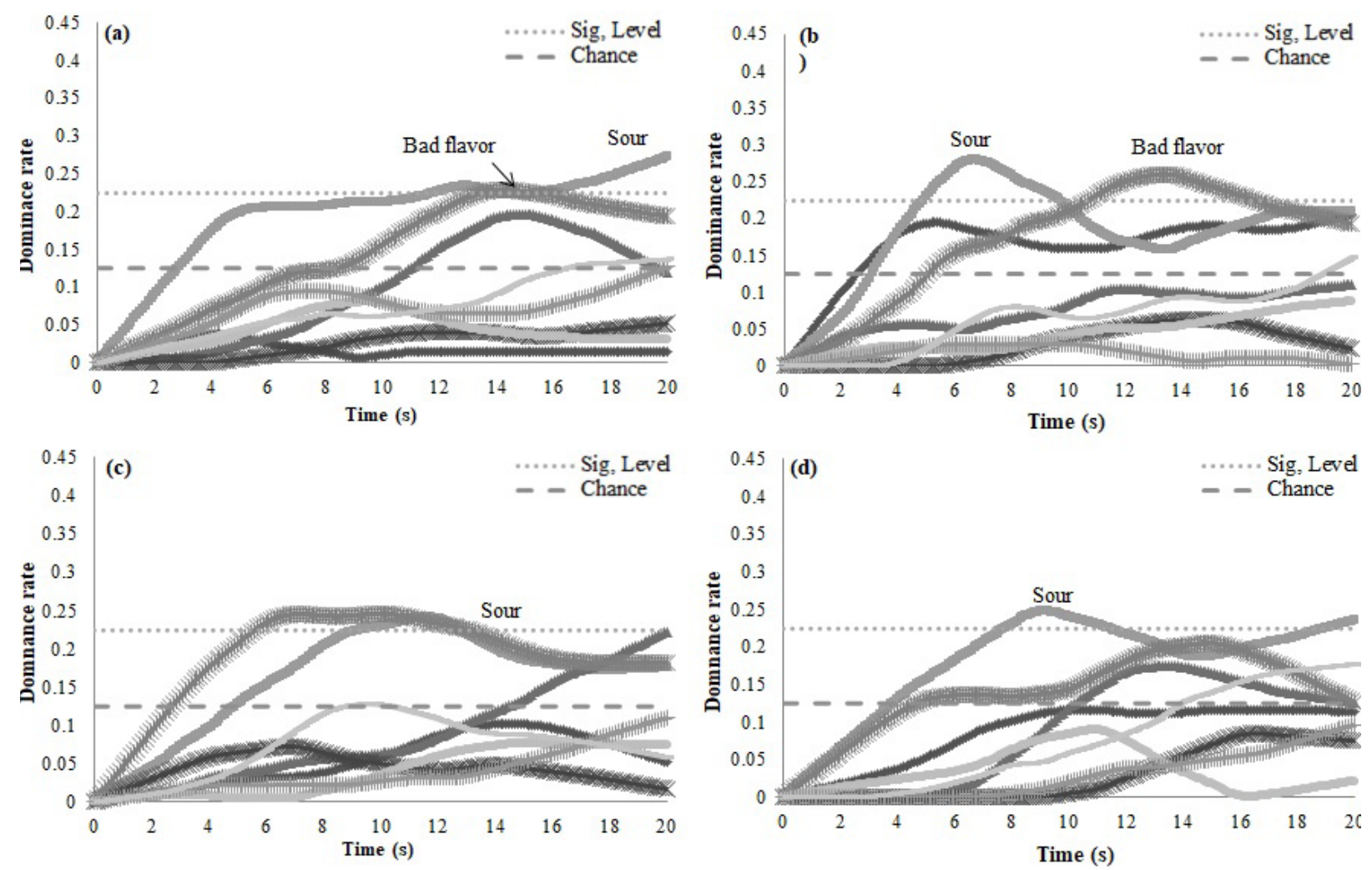

Figure 4: Graphic representation of the temporal dominance of sensations profile generated for mangaba pulp Unpasteurized, frozen by Static Air (UPSA) (a); Unpasteurized frozen by Forced Air (UPFA) (b); Pasteurized frozen by Static Air (PSA) (c); and Pasteurized frozen by Forced Air (PFA) (d) stored for 12 months.

\section{Ideal scale - sweet taste}

Although much of the mangaba is marketed as a raw material for the food industry, it is often consumed in the form of nectar. The lack of previous studies on the ideal sweetness of the nectar of this fruit prompted us to apply an ideal scale technique to identify the optimal concentration of sucrose that should be added. The result of this test will be used to assess the acceptance of the mangaba pulp nectar.

From the responses of the tasters, the linear model described the relationship between the optimal concentrations of sugar for mangaba nectar. The linear equation determined the optimal sucrose concentration $(\mathrm{y}=-3.341+0.3805 \mathrm{x}$, $\mathrm{R}^{2}=0.9988$ ) of $87.8 \mathrm{~g} / \mathrm{L}$. Our results are similar to those of others who applied the ideal scale for the same purpose in nectars of different fruits, such as orange ( $73 \mathrm{~g} / \mathrm{L}$ ) (Pineli et al., 2016), and strawberry (90 g/L) (Gonçalves et al., 2017) but different from that found in another study for umbu and mangaba mixed nectar (140 g/L) (Lima et al., 2018).
Although humans have an innate preference for sweetness, people have different preferences about the level of sweetness, and this can be suppressed by other flavors present in complex food matrices (Methven et al., 2016), as is the case of mangaba.

\section{Acceptance test}

Acceptance testing was conducted on the nectar made from the mangaba pulps with an addition of $87.8 \mathrm{~g} /$ $\mathrm{L}$ of sucrose, the concentration identified as ideal in the ideal scale described.

The ANOVA of the three factors studied (Pasteurization, freezing method and storage time) indicated that there was no significant effect of the freezing methods for the evaluated parameters (appearance, odor, viscosity, flavor and overall impression), nor for the triple interaction between the factors, being only influenced by the interaction between the factors pasteurization and storage time. These mangaba pulp acceptance results resemble those of Souza et al. (2011), who also found 
no difference in the acceptance of orange pulp samples, frozen via static air and the cryogenic method, during 50 days of storage.

With the split of ANOVA, the regression equation indicated that the acceptance of the appearance of the unpasteurized samples decreased linearly $(y=7.07$ $0.11 \mathrm{x} ; \mathrm{R}^{2}=73.21 \%$ ), while the pasteurized samples showed a quadratic behavior $\left(\mathrm{y}=6.77-0.38+0.02 \mathrm{x}^{2}\right.$; $\mathrm{R}^{2}=67.17 \%$ ), also tending to decrease with increasing time. When comparing the acceptance of the two Pasteurized (P) and non-pasteurized (UP) pulps over time, the $\mathrm{P}$ pulp obtained greater acceptance at times $\mathrm{T}=4$ and $\mathrm{T}=8$ of storage, however both obtained equal scores at time zero (average 6.94) and at the end of storage (average 5.30).

As for odor, the regression equation over time was cubic for UP pulp $\left(y=6.36-0.58+0.11-0.005 \mathrm{x}^{3}\right.$; $\left.\mathrm{R}^{2}=100 \%\right)$ and presented linear reduction for P pulp $\left(y=6.13-0.08+0.009 x ; R^{2}=85.05 \%\right)$. Over time, the samples were equal at times $\mathrm{T}=0$ and $\mathrm{T}=8$, but at the end of storage $(T=12)$ the $P$ pulps, obtained greater acceptance (average of 6.42). For the viscosity of the UP samples, there was a linear reduction $(y=6.88$ $0.12+0.005 \mathrm{x}^{2} ; \mathrm{R}^{2}=70.43 \%$ ) over time, while for the P pulps, the equation was quadratic $(y=7.02-0.14+$ $0.01 \mathrm{x}^{2} ; \mathrm{R}^{2}=87.52 \%$ ). When comparing the two levels of pasteurization, the samples remained the same until the fourth month of storage, however with the increase in storage, the P samples were more accepted.
The regression equation for the flavor of the UP samples was linear reduction $\left(y=6.73-0.08 x ; R^{2}=\right.$ $79.34 \%$ ) with increasing time and cubic behavior for $\mathrm{P}$ pulps $\left(y=5.64+0.35-0.07+0.003 \mathrm{x}^{3} ; \mathrm{R}^{2}=67.17 \%\right)$. Although UP pulps have shown greater acceptance at time zero, at the end of storage $(\mathrm{T}=12), \mathrm{P}$ pulps were more accepted.

Figure 5 illustrates that both the UP and P samples had their overall print scores reduced linearly over time, although although the $\mathrm{P}$ pulp had higher scores over eight months, both remained the same $(p<0.05)$ in the end of storage.

In general, the pulps showed a tendency to reduce sensory acceptance with increased storage time in all evaluated attributes. In the comparison between UP and P pulps, pasteurized pulps showed greater acceptance at the end of the storage period for odor, viscosity and flavor and with no significant difference $(\mathrm{p}<0.05)$ at 12 months for overall impression and appearance.

Unsupervised methods, such as PCA and HCA, can be efficient and fast chemometric tools to distinguish differences among samples, depending on the different parameters used (Zielinski et al., 2014) and were selected to complement the analysis of the acceptance results. The PCA results for appearance, odor, viscosity, flavor, and overall impression of mangaba nectar samples are shown in Figure 6. The two main components explained $81.6 \%$ of the variation among samples.

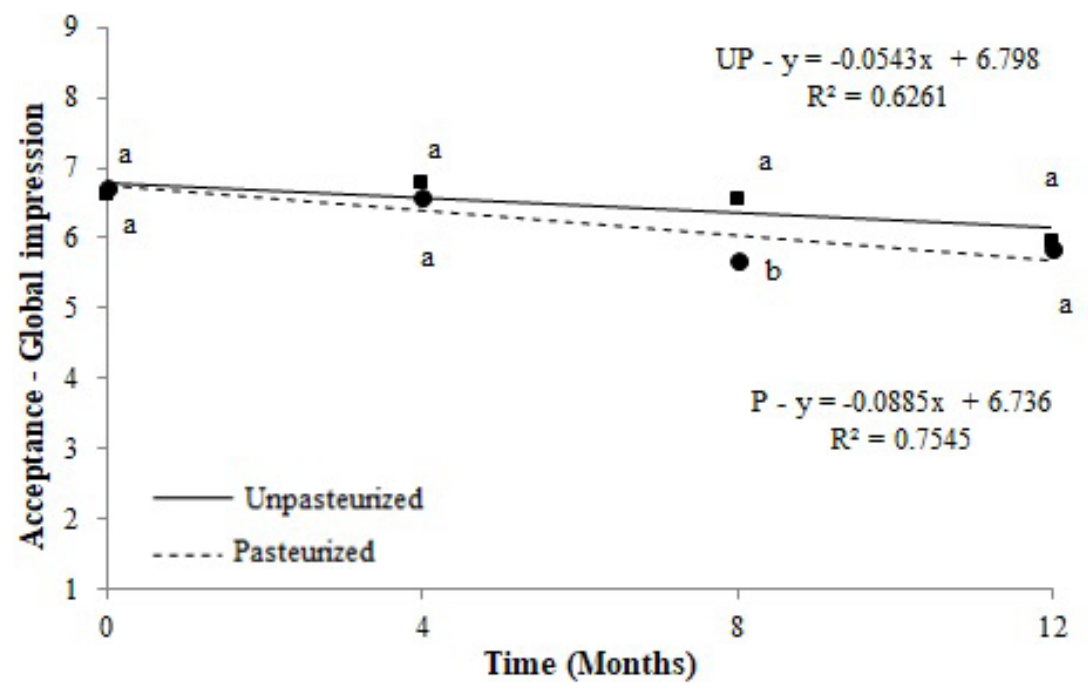

Figure 5: Means values, regression equation and coefficient of determination of the interaction between the factors $x$ time pasteurization for acceptance of the global impression. Means within each storage time labelled with the same letter do not statistically differ from each other by Tukey's test ( $p>0.05)$. 


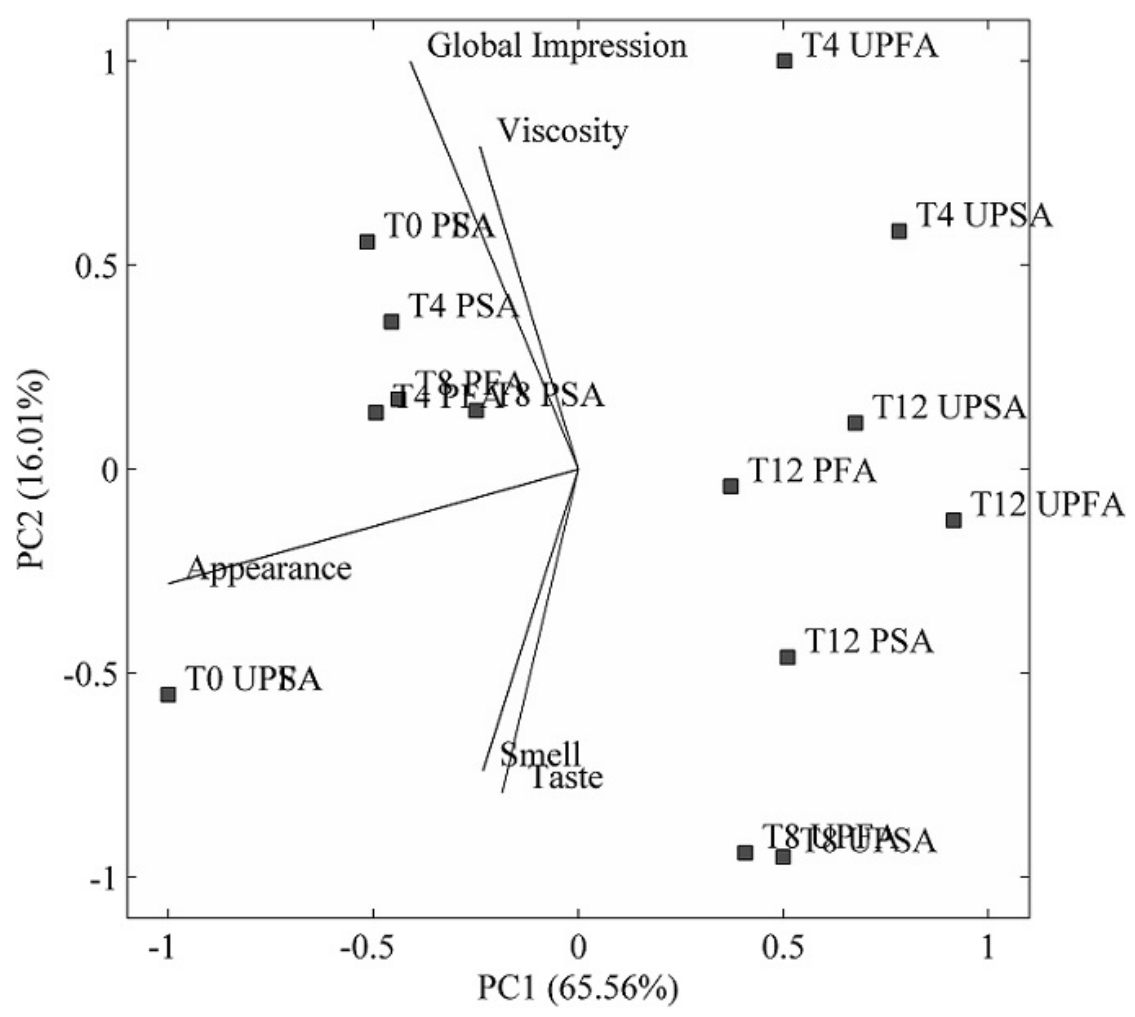

Figure 6: Graphic representation of PCA of mangaba pulp nectar unpasteurized, frozen by Static Air (UPSA); Unpasteurized frozen by Forced Air (UPFA); Pasteurized frozen by Static Air (PSA) and Pasteurized frozen by Forced Air (PFA) stored for T0 $=$ time zero, $\mathrm{T} 4=4$ months $8 \mathrm{~T}=8$ months and $\mathrm{T} 12=12$ months.

According to the PCA chart, samples that showed greater acceptance in all evaluated parameters were those at time zero (UPSA, UPFA, PSA, PFA) and at four and eight months (PSA, PFA), considering the proximity of these samples to all evaluated attributes. The remaining samples (T4 UPSA, T4 UPFA, T8 UPSA, T8 UPFA, T12 UPSA, T12 UPFA, T12 PFA and T12 PSA) showed lower acceptance in all evaluated parameters. These results may be related to the TDS test, indicating that the sour taste (identified at time zero) and cooked flavor (identified at four months of storage) did not compromise the acceptance of these pulps. In a similar study, which evaluated the acceptance of strawberry pulp, unpasteurized and pasteurized samples at zero time were the most accepted in terms of appearance, viscosity and overall impression attributes (Gonçalves et al., 2017).

These data indicate that pasteurization, regardless of the freezing method, ensured greater acceptance for the mangaba pulps for up to 8 months of storage. The unpasteurized pulps, from the fourth month of storage, showed less acceptance than those of time zero, and at 12 months of storage, all samples were less accepted than the others, indicating that the increasing storage time reduces mangaba pulp acceptance. Gonçalves et al. (2017) found that pasteurization decreases acceptance of strawberry pulp, regardless of the freezing method, although they also observed a negative effect of increased storage time on pulp acceptance.

The similarity of the samples was assessed using hierarchical cluster analysis (HCA), which seeks to group samples into classes based on the similarity of the components in the same class and the differences among components of different classes (Beebe; Pell; Seasholtz, 1997).

The Ward method was applied to the HCA to group the 16 samples of mangaba nectar and showed the formation of 2 large groups, considering the Euclidean distance of 1.4, confirming the results of the PCA (Figure 7).

The separation of the groups in relation to greater acceptance can be related to the sensations identified as dominant, in the TDS, as previously discussed and illustrated in Figures 3 and 4. 


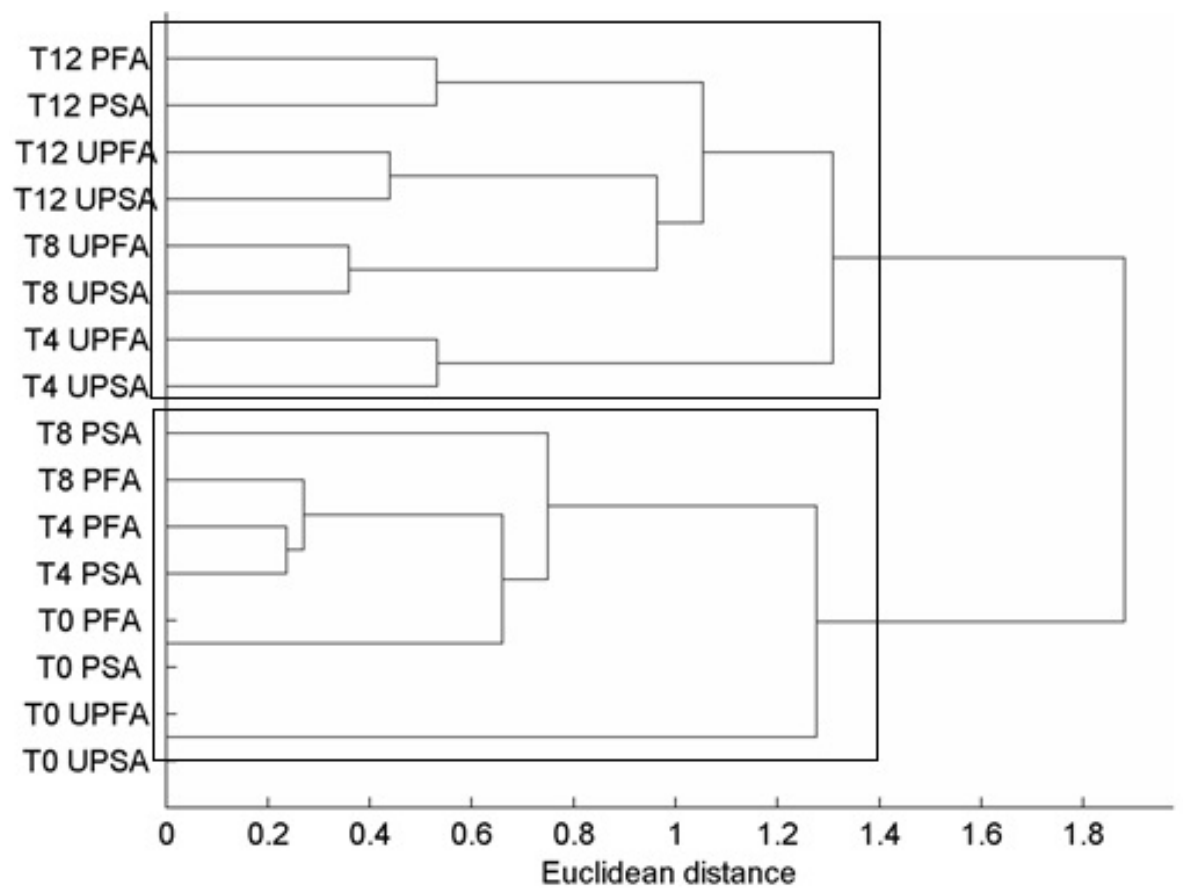

Figure 7: Graphic representation of HCA of mangaba pulp nectar unpasteurized, frozen by Static Air (UPSA); Unpasteurized frozen by Forced Air (UPFA); Pasteurized frozen by Static Air (PSA) and Pasteurized frozen by Forced Air (PFA) stored for T0 $=$ time zero, T4 $=4$ months $8 \mathrm{~T}=8$ months and $\mathrm{T} 12=12$ months. Cluster one, containing all zero time treatments (UPSA, UPFA, PSA, PFA) and PSA and PFA treatments, both in the times four and eight months.

The PCA and HCA findings complemented to ANOVA and allowed us to visualize the differences among samples, particularly in relation to time and pasteurization; in general, shorter storage time and pasteurization had greater acceptance of the tested attributes, regardless of the freezing method.

Similarly, a study by Santos et al. (2018) on the shelf life sensory acceptance of mixed fruit drinks, identified that the beverages presented sweetness reduction after 120 days of refrigerated storage. Reinforcing the effect of storage time on the degradation of fruit drink quality.

However, ANOVA allows us to affirm that, even after 12 months of frozen storage, the pulps continue to have good acceptance, since they presented averages between 5.3 and 6.76 , considering the average of 6.03 , which in the hedonic scale, corresponds a "I liked it slightly".

\section{CONCLUSIONS}

The TDS analysis showed that the sour taste was dominant in most treatments, combined with the identification of a bad flavor in most pulps from 8 months. Our ideal scale evaluation determined that $87.8 \mathrm{~g} / \mathrm{L}$ of added sucrose should yield the optimal flavor for mangaba nectar. The frozen methods by static air or forced air did not significantly influence the sensory acceptance of the mangaba pulp. The pasteurization promotes greater mangaba pulp acceptance for up to eight months; however, after 12 months of storage, all treatments presented good sensory acceptance from consumers, indicating that mangaba pulp can be stored frozen unpasteurized or pasteurized for 12 months.

\section{ACKNOWLEDGMENTS}

The authors thank the National Council for Scientific and Technological Development (CNPq), Coordination for the Improvement of Higher Education Personnel (CAPES), and the Foundation for Research Support of the State of Minas Gerais (FAPEMIG), for the financial support. 


\section{REFERENCES}

ALBERT, A. et al. Comparison between temporal dominance of sensations (TDS) and key-attribute sensory profiling for evaluating solid food with contrasting textural layers: Fish sticks. Food Quality and Preference, 24(1):111-118, 2012.

ASSUMPÇÃO, C. F. et al. Néctar misto de mangaba (Hancoria speciosa Gomes) e cagaita (Eugenia dysenterica): Perfil sensorial e características físico-químicas. Revista Brasileira de Produtos Agroindustriais, 15(3):219-224, 2013.

BHATTACHARJEE, C.; SAXENA, V. K.; DUTTA, S. Novel thermal and non-thermal processing of watermelon juice. Trends in Food Science \& Technology. 93:234-243, 2019.

BEEBE, K. R.; PELL, R. J.; SEASHOLTZ, M. B. Chemometrics: A practical guide. John Wiley \& Sons: New York, 1997. 360p.

BRASIL. Ministério da Agricultura e do Abastecimento. 2000. Instrução Normativa n 1, de 7 de janeiro de 2000. Regulamento técnico geral para fixação dos padrões de identidade e qualidade para polpa de frutas. Diário Oficial da União, 2000, nº 6 .

COSTA, M. C. et al. Conservação da polpa de cupuaçu [Theobroma grandiflorum (Wild. Ex Spreng.) Schum] por métodos combinados. Revista Brasileira de Fruticultura, 25(2):213-215, 2003.

FERREIRA, D. F. SISVAR: A computer analysis system to fixed effects split plot type designs. Revista brasileira de biometria, 37(4):529-535, 2019.

FIGUEIREDO, J. S. B. et al. Sensory evaluation of fermented dairy beverages supplemented with iron and added by Cerrado fruit pulps. Food Science and Technology, 39(2):410-414, 2019.

FROST, S. C.; HARBERTSON, J.; HEYMANN, H. A full factorial study on the effect of tannins, acidity, and ethanol on the temporal perception of taste and mouthfeel in red wine. Food Quality and Preference, 62:1-7, 2017.

GARCIA-REYES, R. H.; NARVAEZ-CUENCA, C. E. The effect of pasteurization on the quality of frozen araza (Eugenia stipitata Mc Vaugh) pulp. Journal of Food Quality, (33):632645, 2010.

GOMES, F. de O. et al. Physical and chemical evaluation of a pequi taste kefir drink. Brazilian Journal of Development, 6(3):10755-10762, 2020.

GONÇALVES, G. A. S. et al. Temporal dominance of sensations for characterization of strawberry pulp subjected to pasteurization and different freezing methods. LWT - Food Science and Technology, 77:413-421, 2017.

HURTADO, A. et al. Application of high pressure processing for pbtaining $B$ fresh-like fruit smoothies. Food and Bioprocess Technology, 8:2470-2482, 2015.

HUTCHINGS, S. C. et al. The effect of training on the temporal dominance of sensations method: A study with milk protein hydrolysates. Journal of Sensory Studies, 32(6):113, 2017.

LABBE, D. et al. Temporal dominance of sensations and sensory profiling: A comparative study. Food Quality and Preference, 20:216-221, 2009.

LIMA, J. P. de et al. Climacteric pattern of mangaba fruit (Hancornia speciosa Gomes) and its responses to temperature. Scientia Horticulturae, 197:399-403, 2015.

LIMA, L. de L. A. et al. Mixed nectar of imbu (Spondias tuberosa Arr. Camera) and mangaba (Hancornia speciosa Gomes): Elaboration and quality evaluation. Brazilian Journal of Food Technology, 21:e2017034, 2018.

MACFIE, H. J. et al. Designs to balance the effect of order of presentation and first-order carry-over effects in hall tests. Journal of Sensory Studies, 4(2):129-148, 1989.

MEILLON, S.; URBANO, C.; SCHLICH, P. Contribution of the Temporal Dominance of Sensations (TDS) method to the sensory description of subtle differences in partially dealcoholized red wines. Food Quality and Preference, 20(7):490-499, 2009.

METHVEN, L. et al. Rejection thresholds (RjT) of sweet likers and dislikers. Food Quality and Preference, 52:74-80, 2016.

NG, M. et al. Using quantitative descriptive analysis and temporal dominance of sensations analysis as complementary methods for profiling commercial blackcurrant squashes. Food Quality and Preference, 25(2):121-134, 2012.

NGUYEN, Q. C.; NAES, T.; VARELA, P. When the choice of the temporal method does make a difference: TCATA, TDS and TDS by modality for characterizing semi-solid foods. Food Quality and Preference, 66:95-106, 2018.

PEREIRA, A. C. et al. Hancornia speciosa Gomes (Apocynaceae) as a potential anti-diabetic drug. Journal of Ethnopharmacology, 161:30-35, 2015.

PERFEITO, D. G. A.; CORRÊA, I. M.; PEIXOTO, N. Elaboração de bebida com extrato hidrossolúvel de soja saborizada com frutos do cerrado. Revista de Agricultura Neotropical, 4(1):21-27, 2017. 
PICOUET, P. et al. Effects of thermal and high-pressure treatments on the microbiological, nutritional and sensory quality of a multi-fruit smoothie. Food and Bioprocess Technology, 9(7):1219-1232, 2016.

PINEAU, N. et al. Temporal dominance of sensations: Construction of the TDS curves and comparison with time-intensity. Food Quality and Preference, 20:450455, 2009.

PINELI, L. L. de O. et al. Sensory impact of lowering sugar content in orange nectars to design healthier, lowsugar industrialized beverages. Appetite, 96:239-244, 2016.

PINHEIRO, A. C. M.; NUNES, C. A.; VIETORIS, V. SensoMaker: a tool for sensorial characterization of food products. Ciência e Agrotecnologia, 37(3):199-201, 2013.

R DEVELOPMENT CORE TEAM. R: A language and environment for statistical computing. Vienna: R Foundation for Statistical Computing, 2016. Available in: <http://www. rproject.org>. Access in: November 10, 2016.

REIS, V. H. O. T. et al. The effects of supplementing Hancornia speciosa (Mangaba) on bowel motility and inflammatory profile of wistar rats. Journal of medicinal food, 22(12):1254-1261, 2019.

ROCHA, C. et al. Elaboração e avaliação de iogurte sabor frutos do cerrado / Elaboration and evaluation of yogurt with cerrado fruits taste. Boletim do Centro de Pesquisa de Processamento de Alimentos, 26(2):255266, 2008.

RODRIGUES, J. F. et al. Temporal dominance of sensations (TDS) panel behavior: A preliminary study with chocolate. Food Quality and Preference, 54:51-57, 2016.
SANTOS, G. Z. dos et al. Aceitação sensorial de bebidas mistas de acerola com juçara ao longo do tempo de estocagem. Higiene Alimentar, 32(278/279):82-86, 2018.

SILVA, M. A. P. da et al. Sensory profile of fermented milk drinks flavored with fruits from the Brazilian Cerrado. African Journal of Food Science and Technology, 9(6):379-389, 2015.

SILVA, N. et al. Manual de métodos de análise microbiológica de alimentos. São Paulo, BR: Livraria Varela. 2007. 536p.

SU, D. et al. Impact of thermal processing and storage temperature on the phenolic profile and antioxidant activity of different varieties of lychee juice. LWT - Food Science and Technology, 116:108578, 2019.

SOUZA, A. L. G. de et al. Avaliação dos níveis de Aceitação e de intenção de compra da polpa de laranja pera congelada e criocongelada. Cientia Plena, 7(3):1-8, 2011.

STONE, H.; SIDEL, J. L. Sensory Evaluation Practices. Orlando, USA: Academic Press, p.56-59, 1993.

VENTURINI FILHO, W. G. Bebidas alcoólicas - Ciência e tecnologia. São Paulo: Blucher. 2010.461p

VICKERS, Z. Sensory specific satiety in lemonade using a just right scale for sweetness. Journal of Sensory Studies, 3(1):1-8, 1988

WU, A. Z. et al. Temporal profiling of simplified lemonade using temporal dominance of sensations and temporal check-allthat-apply. Journal of Sensory Studies, 34(6):e12531, 2019.

ZIELINSKI, A. A. F. et al. The association between chromaticity, phenolics, carotenoids, and in vitro antioxidant activity of frozen fruit pulp in Brazil: An application of chemometrics. Journal of Food Science, 79(4):C510516, 2014. 